REPORTS OF MORPHOLOGY
$\begin{gathered}\text { Official Journal of the Scientific Society of Anatomists, } \\ \text { Histologists, Embryologists and Topographic Anatomists } \\ \text { of Ukraine } \\ \text { journal homepage: https://morphology-journal.com }\end{gathered}$

\title{
Grass pollen morphology investigation as a basis for monitoring of allergenic biological particles in an automatic mode
}

\section{Yasniuk M.V., Kaminska O.A., Rodinkova V.V.}

National Pirogov Memorial Medical University, Vinnytsia, Ukraine

\section{ARTICLEINFO}

Received: 14 June, 2020

Accepted: 10 July, 2020

UDC: $638.138: 582.542: 616-022.8$

\section{CORRESPONDING AUTHOR}

e-mail: yasnyukmarina@gmail.com Yasniuk M.V.

\begin{abstract}
A clear distinction between the morphology of allergenic pollen grains of various genera of the Poaceae family is an important task in determining the causal allergenic factors in the population. It allows significant improvement of the efficiency of seasonal allergy diagnostics caused by grass pollen. Moreover, it let to perform better predictions of allergenic risks for people, suffering from pollinosis caused by Poaceae pollen. Therefore, the aim of our study was to establish the morphological difference between the pollen grains of plants of various species of Poaceae family in order to further determination of the possibility to use the established distinctions for the identification of pollen in aerobiological studies. For this, both herbarium samples and pollen of the studied plants were collected in the field during May-June 2019 in Vinnytsia. The pollen was shaken off the anthers directly onto a glass slide, immediately stained with basic fuchsin, and covered with a cover slip. The sizes of pollen grains - their width and length - were determined and analyzed using the PhotoM 1.21 program, and the obtained data on the sizes of pollen were divided into categories by the quartile method in Excel. Three categories of pollen sizes were identified: large, medium and small. Large grains had width and length parameters of $40 \mu \mathrm{m}$ or more, average grains ranged from 26 to 39 $\mu \mathrm{m}$, and small grains had a size of $26 \mu \mathrm{m}$ or lesser in width and length. The large category includes the pollen of Hordeum morinum (39.5-53.1 $\mu \mathrm{m})$, Elytrigia repens (41-48 $\mu \mathrm{m})$, Secale cereale (48.4-62.5 $\mu \mathrm{m})$ and Bromus arvensis (42.2-52.7 $\mu \mathrm{m})$. The medium grain category included pollen from Dactylis glomerata (29.2-38.1 $\mu \mathrm{m})$, Poa spp. (26.137.3 $\mu \mathrm{m})$, Panicum capillare (33.3-39.5 $\mu \mathrm{m})$, Lolium perenne (30.4-35.3 $\mu \mathrm{m})$, Bromus sterilis (28.3-30.8 $\mu \mathrm{m})$. The pollen size of $B$. ramosus ranged from 26.1 to $39.5 \mu \mathrm{m}$, and $B$. tectorum was from 35 to $38.4 \mu \mathrm{m}$. The pollen grains of Poa pratense (22.1-25.9 $\mu \mathrm{m})$ and Piptatherum spp were assigned to the category of the smallest pollen (20.3-24.1 microns). Agrostis gigantea was the only grass pollen type whose size fitted for each category. We found out large, medium-sized and grains of 25.0-27.7 microns, which lie between categories 2 and 3 , for different populations of this plant. Consequently, some genera and species of Poaceae can be distinguished by the size of their pollen, while in others the size of pollen grains varies considerably. It is necessary to carry out further research that will help to establish the morphology of pollen of a larger number of Grass family plants. This will significantly improve the diagnosis and prevention of seasonal allergy caused by grass pollen in Ukraine.

Key words: allergenic pollen, allergenic biological particles, seasonal allergy, grass pollen, pollen sensitivity, pollinosis prevention.
\end{abstract}

\section{Introduction}

Gramineae (Poaceae) or grasses are a large family of about 8,000 species. Representatives of this family are common herbs. They cover about $20 \%$ of the land surface. Grasses made a great contribution to the development of human culture, as they were one of the first plants grown by man, helping him to move from hunting and gathering the gifts of nature to agriculture. This happened about 10,000 years ago. Cereals such as wheat (Triticum) and barley (Hordeum) are still the most important sources of food for humans [27].

However, today the topic of grasses is becoming increasingly important given the high allergenicity of plants 
of this family, including their pollen. After all, people are constantly exposed to it during the flowering of ornamental or those grasses that are used for landscaping lawns in settlements [16].

Thus, currently, the pollen of Poaceae family plants has become one of the most important factors of seasonal allergy in the world $[5,11]$. In temperate climates, it contributes significantly in the level of sensitization of patients, along with pollen of ragweed and trees, in particular, birch $[4,8,19]$. According to molecular diagnostics of allergies [25], in Ukraine about $40 \%$ of patients with seasonal allergies are sensitive to grass pollen allergens. The same percentage of people with atopy react to grass pollen in Turkey. In other parts of the world, this number varies, but is also high. For example, in Switzerland, 12\% of those with symptoms of seasonal allergy are sensitive to pollen [10], and in Australia, 29 to $41 \%$ of people with hay fever are sensitized to pollen too [6]. Therefore, it is not surprising that grass pollen is included into the list of pollen grain species for which allergy risk forecasts are most often made in Europe and in the world [15].

Moreover, both in Ukraine [25] and in the world [6], allergenicity of pollen of different species of the family Poaceae is considered [27]. These include Timothy (Phleum pratensis) and English ryegrass (Lolium perenne). Pollen allergens of these species are one of the main known factors of seasonal allergy [9, 26].

Thus, in Ukraine, $38.8 \%$ of people with hay fever are sensitive to meadow timothy' allergens, $28.8 \%$ - to English ryegrass, and $14.3 \%$ - to rye pollen [25]. There are also data on the allergenicity of pollen from other representatives of plants of the grass family - cock's-foot or orchard grass (Dactylis glomerata), Kentucky bluegrass (Poa pratensis) and Bermuda grass (Dhoob, dūrvā grass) (Cynodon dactylon) [2].

Flowering of all these species of Poaceae can both coincide and be observed in different periods of pollination of plants of the family. Therefore, pollen grains produced by plants at different times may be of clinical importance for different patients. From the point of view of the importance of these plants in terms of the ability to cause pathological symptoms in patients, it is important to inform them about the flowering of different species of plants at different times.

To date, the accuracy of aerobiological predictions of pollen distribution for plants of the Poaceae family is only relative: when counting and identifying pollen during aerobiological observations, grass pollen grains are gathered into one category - Poaceae. Therefore, when creating allergy forecasts [24], the risk levels due to the pollination of grasses are assessed for the family as a whole, and not for its individual species. However, as already mentioned, such an assessment could have a higher practical and clinical significance, given that it would allow for a more accurate diagnosis and prevention of pollinosis caused by grass pollen. This, in turn, could significantly save the population and the health care system' costs associated with treating seasonal allergies to grass pollen, in particular by allergen immunotherapy. The latter can last year-round in severe, late-diagnosed clinical casesand is expensive though [13].

Therefore, the aim of our study was to establish the morphological difference between the pollen grains of plants of different species of the family Poaceae to further determine the possibility of using the established difference in the identification of pollen in aerobiological studies.

\section{Materials and methods}

Pollen of the studied plants was collected in the city of Vinnytsia (Ukraine) directly from plant inflorescences (spikes or panicles) in the field during May and June 2019. Along with pollen samples, samples of the herbarium of selected plants were collected. The pollen was shaken out from the anthers directly onto a microscopic slide, immediately stained with a gelatin-based stain and stored in a thermos. The stain contained basic fuchsin. The chemical composition of the stain was identical to that, which is standardly used for staining pollen samples in aerobiological studies. After staining, the sample was covered with a cover glass. A total of 60 pollen samples from different plants were collected.

The first, test collection of pollen grains, was held on May 14, 2019. Its purpose was to determine the pollination activity of Poaceae family species that are among the first to emit pollen. In particular, wall barley (Hordeum murinum), rice grass (Piptatherum spp.), cock's-foot or orchard grass (Dactylis glomerata) and Kentucky bluegrass (Poa pratensis). At this time, the first 15 samples were collected, which did not show pollen grains. Therefore, despite the formed inflorescences, it was found out that the pollen of grasses at that time was still immature enough to be shaken off the anthers and, accordingly, cause symptoms of pollinosis.

A second attempt was made on May 30, 2019 and it had a positive result: 9 samples of pollen from different plants were obtained. During further collecting on June 1, 2019 and June 9, 2019 another 36 samples were collected. In total, grass pollen grains were detected in 45 samples. The obtained samples were analyzed using the method of light microscopy with a magnification of $x 400$. This magnification is a standard for the identification of pollen grains.

Stained pollen grains were selected for getting their morphological parameters only after examination of the entire sample. This was done in order to be sure that pollen in one sample had the same size and shape, and to confirm that the collected pollen belongs to the same species.

When reviewing the selected samples, it was noteworthy that the pollen grains of grasses were of different shapes and sizes, had different structure and were differently saturated with the color of the stain, had different pore sizes. 
Table 1. Indicators of width and length of pollen grains of the studied grass species $(M \pm m), \mu m$.

\begin{tabular}{|c|c|c|}
\hline Species & Width & Length \\
\hline Wall barley (Hordeum morinum) & $45,68 \pm 4,47$ & $47,60 \pm 3,41$ \\
\hline Rye (Secale cereale) & $61,60 \pm 0,90$ & $51,20 \pm 2,80$ \\
\hline Couch grass (Elytrigia) & $45,68 \pm 4,32$ & $47,60 \pm 3,05$ \\
\hline Field brome (Bromus arvensis) & $45,75 \pm 3,55$ & $48,55 \pm 4,15$ \\
\hline $\begin{array}{l}\text { Cock's-foot or orchard grass (Dactylis } \\
\text { glomerata) }\end{array}$ & $30,97 \pm 2,93$ & $33,23 \pm 2,72$ \\
\hline Meadow-grass (Poa) & $30,80 \pm 4,25$ & $32,60 \pm 4,70$ \\
\hline Annual meadow grass (Poa annua) & $30,80 \pm 3,53$ & $33,70 \pm 3,87$ \\
\hline Downy brome (Bromus tectorum) & $38,23 \pm 0,54$ & $34,97 \pm 1,76$ \\
\hline Barren brome (Bromus sterilis) & $29,45 \pm 1,15$ & $29,55 \pm 1,25$ \\
\hline Hairy brome (Bromus ramosus) & $31,77 \pm 4,05$ & $35,20 \pm 3,64$ \\
\hline Brome grasses (Bromus) & $38,15 \pm 0,65$ & $34,95 \pm 2,15$ \\
\hline Kentucky bluegrass (Poa pratensis) & $23,35 \pm 1,25$ & $25,45 \pm 0,45$ \\
\hline Ricegrass (Piptatherum) & $20,65 \pm 0,35$ & $23,45 \pm 0,65$ \\
\hline
\end{tabular}

Finally, a preliminary study found that pollen grain size varied the most (from $60 \mu \mathrm{m}$ to $20 \mu \mathrm{m}$ ). Therefore, this parameter was chosen for further evaluation.

To get the linear dimensions, reference samples were selected without any mechanical damage. For pollen of each plant species, measurements were made at least three times to obtain their average value. For pollen grains of all categories, the average value of width and length, as well as the standard deviation were calculated (Table 1).

Grass species' definition was made in accordance with Ukrainian botanical atlases [20, 29] and Internet sources using the botanical specimens taken in a field after pollen collection.

PhotoM 1.21 program was used for accurate measurement of pollen grain size. This program made it possible to use photographs taken from a light microscope with a field of view having calibrated scale (Fig. 1). Analysis of sample sizes was continued in Excel using the quartile method.

The study of the morphology of grass pollen is a

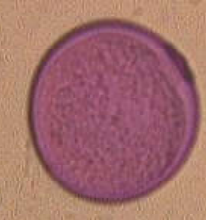

A

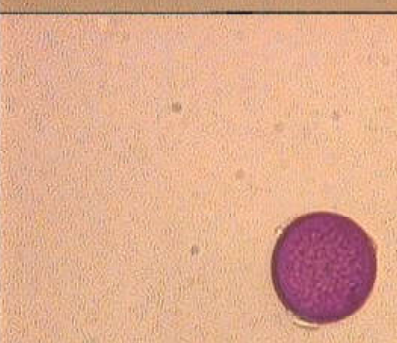

B

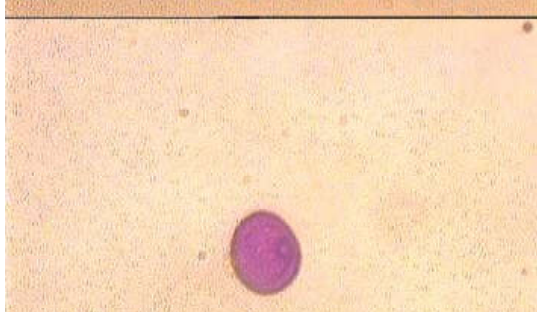

C

$\mathrm{C} 1$

B1
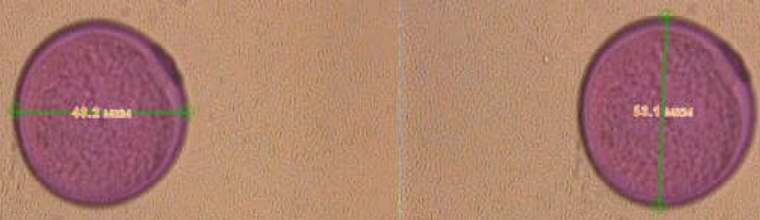

A2
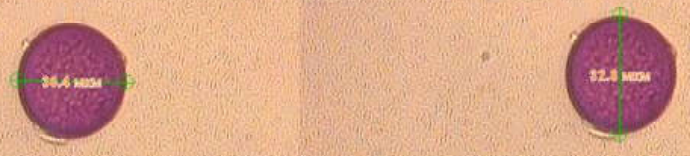

B2

\section{$\mathrm{C} 2$}

Fig. 1. Microscopic photos of pollen obtained in the program PhotoM 1.21. x400. Grass pollen of different categories: A - 1 category (Hordeum morinum), B - 2 category (Lolium perenne), C - 3 category (Piptatherum Spp.). A (Hordeum morinum): A1 - 48,2 $\mu$ m of width and A2 -53,1 $\mu$ m of length; B (Lolium perenne): B1 - width is $30,4 \mu \mathrm{m}$ and B2 - length is $32,8 \mu \mathrm{m}$; C (Piptatherum Spp.): $\mathrm{C} 1$ - width is $20,3 \mu \mathrm{m}$ and $\mathrm{C} 2$ - length is $24,1 \mu \mathrm{m}$. 
promising scientific field in terms of diagnosis and prevention of hay fever. After all, pollen of grass species remains the leading allergenic agent of air. Moreover, the effectiveness of treatment of sensitivity to it depends on the exact definition of the causative agent of hay fever [18].

\section{Results}

The program divided the indicators of the linear size of the pollen into 4 quartiles as follows:

1st quartile: width - 62.5-38.4 $\mu \mathrm{m}$, length 54.0-39.5 $\mu \mathrm{m}$

2nd quartile: width - 37.5-32.1 $\mu \mathrm{m}$, length 38.1-33.7 $\mu \mathrm{m}$ 3rd quartile: width - 31.7-26.1 $\mu \mathrm{m}$, length 33.3-28.3 $\mu \mathrm{m}$ 4th quartile: width - 25.9-20.3 $\mu \mathrm{m}$, length 27.9-22.8 $\mu \mathrm{m}$.

Using the obtained data, with the help of "Excel" we obtained a clear selection of 3 categories of linear sizes of pollen grains (Fig. 2):

1. Large - width and length are greater than $40 \mu \mathrm{m}$;

2. Medium - width and length are in the range of $26-39 \mu \mathrm{m}$;

3. Small - width and length are less than $26 \mu \mathrm{m}$.

The category of large pollen grains included pollen of Hordeum morinum (39.5-53.1 $\mu \mathrm{m})$, Elytrigia repens (41$48 \mu \mathrm{m})$, Secale cereale $(48.4-62.5 \mu \mathrm{m})$ and Bromus arvensis (42.2- $52.7 \mu \mathrm{m})$.

Medium-sized grains included pollen of Dactylis glomerata (29.2-38.1 $\mu \mathrm{m})$, Poa spp. (26.1-37.3 $\mu \mathrm{m})$, Panicum capillare (33.3-39.5 $\mu \mathrm{m})$, Lolium perenne (30.4$35.3 \mu \mathrm{m})$, Bromus sterilis $(28.3-30.8 \mu \mathrm{m})$. The pollen size of $B$. ramosus ranged from 26.1 to $39.5 \mu \mathrm{m}$, and $B$. tectorum from 35 to $38.4 \mu \mathrm{m}$.

The smallest category included pollen Poa pratense (22.1-25.9 $\mu \mathrm{m})$ and Piptatherum spp. (20.3-24.1 $\mu \mathrm{m})$.

The only species whose pollen size was suitable for all categories was Agrostis gigantea. For different populations of this plant, we found large, medium and grains of 25.0$27.7 \mu \mathrm{m}$, the size of which was between the categories of "medium" and "small" (Table 2).

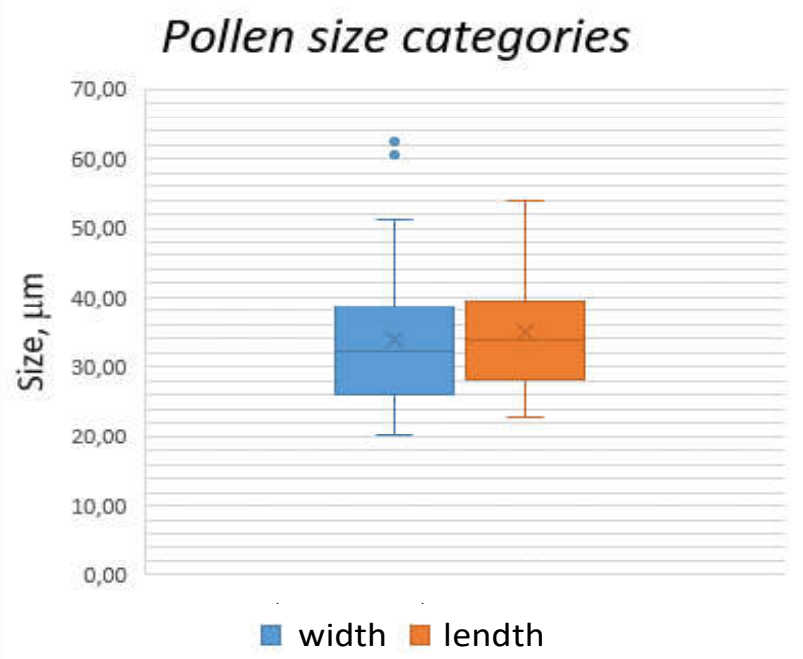

Fig. 2. Separation of grass pollen into categories by size (by width and length).
Table 2. Black bent (Agrostis gigantea). Variation of sizes on different samples of one specie $(\mathrm{M} \pm \mathrm{m}), \mu \mathrm{m}$.

\begin{tabular}{|c|c|c|c|}
\hline \multicolumn{4}{|c|}{ Agrostis gigantea } \\
\hline \multirow{2}{*}{ sample } & Width & Length & category \\
\hline 55 & $40,60 \pm 2,40$ & $42,60 \pm 2,20$ & 1 \\
\hline 53 & $35,90 \pm 0,30$ & $37,50 \pm 0,60$ & 2 \\
\hline $55 \mathrm{~A}$ & $30,10 \pm 0,75$ & $30,40 \pm 1,90$ & 2 \\
\hline 52 & $25,90 \pm 0,20$ & $27,70 \pm 2,90$ & 3 \\
\hline 54 & $26,10 \pm 0,12$ & $27,00 \pm 2,40$ & 3 \\
\hline $53 \mathrm{~A}$ & $25,00 \pm 0,14$ & $26,60 \pm 0,34$ & 3 \\
\hline
\end{tabular}

Table 3. Distribution of pollen grains sizes among the respective categories.

\begin{tabular}{|c|c|c|}
\hline Species whose pollen has been identified & $\begin{array}{l}\text { Date of } \\
\text { collection }\end{array}$ & $\begin{array}{l}\text { Pollen } \\
\text { category }\end{array}$ \\
\hline Wall barley (Hordeum morinum) & 30.05 .2019 & 1 \\
\hline $\begin{array}{c}\text { Cock's-foot or orchard grass (Dactylis } \\
\text { glomerata) }\end{array}$ & 30.05 .2019 & 2 \\
\hline Kentucky bluegrass (Poa pratensis) & 30.05 .2019 & 3 \\
\hline (Ricegrass (Piptatherum) & 30.05 .2019 & 3 \\
\hline $\begin{array}{l}\text { Cock's-foot or orchard grass (Dactylis } \\
\text { glomerata) }\end{array}$ & 01.06 .2019 & 2 \\
\hline Meadow-grass (Poa) & 01.06 .2019 & 2 \\
\hline Witchgrass (Pancium capillare) & 01.06 .2019 & 2 \\
\hline $\begin{array}{l}\text { English ryegrass or perennial ryegrass } \\
\text { (Lolium perenne) }\end{array}$ & 01.06 .2019 & 2 \\
\hline Barren brome (Bromus sterilis) & 01.06 .2019 & 2 \\
\hline Hairy brome (Bromus ramosus) & 01.06.2019 & 2 \\
\hline Wall barley (Hordeum morinum) & 09.06.2019 & 1 \\
\hline Couch grass (Elytrigia) & 09.06.2019 & 1 \\
\hline Rye (Secale cereale) & 09.06 .2019 & 1 \\
\hline Field brome (Bromus anvensis) & 09.06 .2019 & 1 \\
\hline $\begin{array}{l}\text { Cock's-foot or orchard grass (Dactylis } \\
\text { glomerata) }\end{array}$ & 09.06 .2019 & 2 \\
\hline Annual meadow grass (Poa annua) & 09.06.2019 & 2 \\
\hline Brome grasses (Bromus) & 09.06.2019 & 2 \\
\hline Downy brome (Bromus tectorum) & 09.06 .2019 & 2 \\
\hline Kentucky bluegrass (Poa pratensis) & 09.06 .2019 & 3 \\
\hline
\end{tabular}

To exclude the possibility of the impact of the gradual maturation of pollen on the final results, they were summarized in one table, which clearly showed that the size of the pollen did not depend on the time when it was collected.

Pollen of different categories was collected on each date indicated in the table. Pollen of the same species, which was collected on different dates, belonged to the same categories (Table 3).

\section{Discussion}

Grass pollen is not only the main factor of hay fever in the world [1], it also acts as an initiating factor that causes 
the development of pollen allergy in general since childhood $[19,30]$.

However, insufficient attention is given in the scientific literature to the issue of studying the morphology of grass pollen. Available sources indicate the interest of scientists in studying the structure of pollen in agriculture [22], as well as - the interest in fossil pollen studies [12, 23].

At the same time, papers on the identification of grass pollen for aerobiological and allergological research are rare [8].

However, comparing the obtained data with the results of studying the morphology of grass pollen in the air, we can state that our data correlate with the data represented by other authors. In particular, rye pollen is known for its large size, and in our study it also got to the largest category. But Agrostis pollen, which in our study did not receive a clear category, was classified by L.N. Morgado and co-authors as pollen with small size [17]. These and other researchers [21] also divide grass pollen into three categories by size large, medium and small. Moreover, the large pollen category includes pollen greater than $46 \mu \mathrm{m}$, and small - less than $22 \mu \mathrm{m}$, which roughly corresponds to the categories obtained in our study.

However, the morphology of grass pollen remains an unclear scientific question. This is because Poaceae family pollen is mostly spherical in size and has one pore. Therefore, scanning electron microscopy [3, 14] and spectroscopy [7] are used for its in-depth study. The latter technique can also be used to detect pollen automatically. However, there have been reports of evolutionary changes in the Poaceae family and the appearance of pollen with 2 pores [22]. The morphology of such pollen can be quickly

\section{References}

[1]Al-Nesf, M. A., Gharbi, D., Mobayed, H. M., Dason, B. R., Ali, R. M., Taha, S. ... del Mar Trigo, M. (2020). The association between airborne pollen monitoring and sensitization in the hot desert climate. Clin. Transl. Allergy., 10, 35. doi: 10.1186/ s13601-020-00339-6

[2] Anallergo immunotherapy research, n.d. Grass Mix Allergen Datasheet. Retrieved from: https://www.anallergo.it/en/ patients/allergens/grass-pollens/grasses-(poaceae-orgramineae)-mix.html

[3] Andersen, T. S., \& Bertelsen, F. (1972). Scanning Electron Microscope Studies of Pollen of Cereals and other Grasses. Grana, 12(2), 79-86. doi: 10.1080/00173137209428830

[4] Bjerg, A., Ekerljung, L., Eriksson, J., Näslund, J., Sjölander, S., Rönmark, E. ... Lundbäck, B. (2016). Increase in pollen sensitization in Swedish adults and protective effect of keeping animals in childhood. Clinical \& Experimental Allergy, 46(10), 1328-1336. doi: 10.1111/cea.12757.

[5] Damialis A., Traidl-Hoffmann C., \& Treudler R. (2019). Climate Change and Pollen Allergies. In: Marselle M., Stadler J., Korn $\mathrm{H}$., Irvine K., Bonn A. (eds) Biodiversity and Health in the Face of Climate Change. Springer, Cham. doi: 10.1007/9783-030-02318-8_3

[6] Davies, J. M., Berman, D., Beggs, P. J., Ramón, G. D., Peter, J., Katelaris, C. H., \& Ziska, L. H. (2020). Global Climate Change and Pollen Aeroallergens; A Southern Hemisphere perspective. determined using cheap and fast approaches used in aerobiology.

Therefore, the preliminary categorization of grass pollen and determination of their morphology using light microscopy remains an important approach of modern aerobiology.

The prospect of our further development and research is to further investigate the morphology of grass pollen that have already been selected for preliminary research, to expand the range of Poaceae family species under study, and to include in the morphological characteristics of pollen grains such indicators as pollen grain' volume, its width and length. Latter will lead to the determination of their shape.

These studies can be useful for both conventional aerobiological investigations and for automatic pollen monitoring.

\section{Conclusions}

Further study of the pollen morphology of Poaceae family plants is a promising practical area of both aerobiological and allergological research.

According to the linear sizes of pollen grain, three categories of grass pollen are defined - large, medium and small.

Some genera and species of the Poaceae family can be distinguished by the size and shape of their pollen, while in other cases the pollen varies considerably.

Further research is needed to determine the morphology of Poaceae pollen, the exact time of flowering of family species and the coincidence of periods of active pollination with data on exacerbations of human sensitivity to grass pollen in Ukraine.

Immunology and Allergy Clinics of North America. doi: 10.1016/j.iac.2020.09.002

[7] Diehn, S., Zimmermann, B., Tafintseva, V.,Bagcioglu, M., Kohler, A., Ohlson, M. ... Kneipp, J. (2020). Discrimination of grass pollen of different species by FTIR spectroscopy of individual pollen grains. Analytical and Bioanalytical Chemistry, 412, 6459-6474. doi: 10.1007/s00216-020-02628-2

[8] Douladiris, N., Garib, V., Focke-Tejkl, M., Valenta, R., Papadopoulos, N. G., \& Linhart, B. (2018). Detection of genuine grass pollen sensitization in children by skin testing with a recombinant grass pollen hybrid. Pediatric allergy and immunology, 30(1), 59-65. doi: 10.1111/pai.12991

[9] Fernandez-Gonzalez, D., Rodriguez Rajo, F.J., Gonzalez Parrado, Z., Valencia Barrera, R. M., Jato, V., \& Grau, S. M. (2011). Differences in atmospheric emissions of Poaceae pollen and Lol p 1 allergen. Aerobiologia, 27, 301-309. doi: 10.1007/s10453-011-9199-x

[10] Gangl, K., Niederberger, V., \& Valenta, R. (2013). Multiple grass mixes as opposed to single grasses for allergen immunotherapy in allergic rhinitis. Clin. Exp. Allergy, 43(11), 1202-1216. doi: 10.1111/cea.12128

[11] Garcia-Mozo, H., (2017). Poaceae pollen as the leading aeroallergen worldwide: A review. European journal of allergy and clinical immunology, 72(12), 1849-1858. doi: 10.1111/ all.13210. 
[12] Liu, Q., Zhao, N-X., \& Hao, G. (2004). Pollen morphology of the Chloridoideae (Gramineae), Grana, 43(4), 238-248. doi: 10.1080/00173130410000776

[13] Mahler, V., Zielen, S., \& Rosewich, M. (2019). Year-round treatment initiation for a 6 -grasses pollen allergoid in specific immunotherapy of allergic rhinoconjunctivitis and asthma. Immunotherapy. Retrieved from: https:// www.futuremedicine.com/doi/10.2217/imt-2019-0086. doi: 10.2217/imt-2019-0086

[14] Mander, L., Li, M., Mio, W., Fowlkes, C. C., \& Punyasena, S. W. (2013). Classification of grass pollen through the quantitative analysis of surface ornamentation and texture. Proceedings of the Royal Society Biological Sciencies, 280(1770). doi: 10.1098/rspb.2013.1905

[15] Maya-Manzano, J. M., Smith, M., Markey, E., Clancy, J. H., Sodeau, J., \& O'Connor, D. J. (2020). Recent developments in monitoring and modelling airborne pollen, a review. Grana. doi: 10.1080/00173134.2020.1769176

[16] Mclnnes, R. N., Hemming, D., Burgess, P., Lyndsay, D., Osborne, N. J., Skjøth, C. A. ... Vardoulakis, V. (2017). Mapping allergenic pollen vegetation in UK to study environmental exposure and human health. The Science of the Total Environment, 599600, 483-499. doi: 10.1016/j.scitotenv.2017.04.136

[17] Morgado, L. N., Goncalves-Esteves, V., Resendes, R., \& Mateus Ventura, M. A. (2015). Pollen morphology of Poaceae (Poales) in the Azores, Portugal. Grana, 54(4), 282-293. doi: 10.1080/ 00173134.2015 .1096301

[18] Pfaar, O., Hohlfeld, J. M., Al-Kadah, B., Hauswald, B., Homey, B., Hunzelmann, N. ... Klimek, L. (2017). Dose-response relationship of a new Timoty grass pollen allergoid in comparison with a 6-grass pollen allergoid. Clinical Trial, Clin. Exp. Allergy, 47(11), 144-1455. doi: 10.1111/cea.12977

[19] Pointner, L., Bethanis, A., Thaler, M., Traidl-Hoffmann, C., Gilles, S., Ferreira, F., \&Aglas, L. (2020). Initiating pollen sensitizationcomplex source, complex mechanisms. Clinical and Translational Allergy, 10, 36. doi: 10.1186/s13601-020-00341-y

[20] Prokudyn, Y., \& Vovk, A. (1977). Grasses of Ukraine. Kiev: Scientific Thought.

[21] Radaeski, J. N., Bauermann. S. G., \& Pereira, A. B. (2016). Poaceae Pollen from Southern Brazil: Distinguishing Grasslands (Campos) from Forests by Analyzing a Diverse Range of Poaceae Species. Frontiers in Plant Science,
7(1833). doi: 10.3389/fpls.2016.01833

[22] Radaeski, J. N., Cunha, D. J., \& Bauermann, S. G. (2017). Diporate pollen grains of Poaceae speices: high pollen resolution for reconstruction of grasslands vegetation. Open access journal of agricultural research, 2(3). doi: 10.23880/ OAJAR-16000135

[23] Radaeski, J. N., Evaldt, A. N. P., \& Bauermann, S. G. (2018). Anthropic pollen indicators: Poaceae pollen of non-native species in Southern Brazil. Open Access Journal of Agricultural Research, 2(2). doi: 10.15406/ oajs.2018.02.00059

[24] Rodinkova, V. V. (2011). Pollen forecast is a service for doctors and patients that is developing in Vinnytsia. "News of Medicine and Pharmacy" Allergology and Pulmonology. Retrieved from: http://www.mif-ua.com/archive/issue-21193/

[25] Rodinkova, V., \& Yuryev, S., (2019). The population sensitivity to the pollinosis factors in Ukraine according to the molecular allergy diagnosis ALEX. Clinical immunology. Allergy. Infectology, 2(115), 22-26. Retrieved from: https://kiai.com.ua/ ua/archive/2019/2\%28115\%29/pages-22-26/chutlivistnaselennya-do-chinnikiv-polinozu-v-ukrayini-za-danimimolekulyarnoyi-diagnostiki-alergiyi-alex-

[26] Ščevková, J., Vašková, Z., Sepšiová, R., Dušička, J., \& Kováč, J. (2020). Relationship between Poaceae pollen and Phl p 5 allergen concentrationsand the imact of weather variables and air pollutants on their levels inthe atmosphere. Heliyon 6(7). doi: 10.1016/j.heliyon.2020.e04421

[27] Steinmann, H., \& Ruden, S. (2004). Grass pollens: Allergy which allergens? Uppsala: Pharmacia Diagnostics.

[28] Türe, C. (2016). Allergenic airborne Poaceae (grass) pollen around public transportation centers in Eskisehir, Turkey. South Western Journal Horticulture, Biology and Environment, 7(1), $1-14$.

[29] Veselovskyi, I. V., Lysenko, A. K., \& Manko, Y. P. (1988). Atlas - determinant of weeds. Kyiv: Harvest.

[30] Westman, M., Aberg, K., Apostolovic, D., Lupinek, C., Gattinger, P., Mittermann, I. . . van Hage, M. (2020). Sensitization to grass pollen allergen molecules in a birth cohort-natural $\mathrm{Phl} p 4$ as an early indicator of grass pollen allergy. Journal of Allergy and Clinical Immunology, 145(4), 1174-1181. doi: 10.1016/ j.jaci.2020.01.006

\section{ВИВЧЕННЯ МОРФОЛОГІЇ ПИЛКУ ЗЛАКІВ ЯК ПІДґРУНТЯ МОНІТОРИНГУ АЛЕРГЕННИХ БІОЛОГІЧНИХ ЧАСТОК В АВТОМАТИЧНОМУ РЕЖИМІ \\ Яснюк М.В., Камінська О.А., Родінкова В.В.}

Чітке розрізнення морфології алергенних пилкових зерен різних родів родини Тонконогових (Роасеае) $\epsilon$ важливою задачею при визначенні чинників алергії у населення. Воно дозволяє як значно підвищувати ефективність діагностики сезонної алергії, викликаної пилком злаків, так і створювати більш точні прогнози сезонних ризиків для людей, котрі потерпають від алергії до пилку різних видів злаків. Відтак, метою нашого дослідження було встановлення морфологічної відмінності між пилковими зернами рослин різних видів родини Роасеае для подальшого визначення можливості використовувати встановлену відмінність при ідентифрікації пилку в аеробіологічних дослідженнях. Для цього у польових умовах впродовж травня-червня місяия 2019 року у Вінниці збирали гербарні зразки й пилок досліджуваних рослин. Пилок струшували з пиляків безпосередньо на предметне скло і одразу забарвлювали основним фуксином та закривали покривним склом. Розміри пилкових зерен - їх ширину та довжину - визначали та аналізували за допомогою програми Рhоtом 1.21, а квартильним методом у програмі Ехсеl отримали цифрові дані щодо розмірів пилку, котрі в подальшому були розділені на 3 відповідні категорії: великий розмір пилку, середній та малий. Великі зерна мали параметри ширини й довжини 40 мкм і більще, середні зерна були від 26 до 39 мкм, а дрібний пилок становив 26 мкм та менше за шириною та довжиною. До категорії великих увійшов пилок Hordeum morinum (39,5-53,1 мкм), Elytrigia repens (41-48 мкм), Secale cereale (48,4-62,5 мкм) ma Bromus arvensis (42,252,7 мкм). Категорія середніх зерен включала пилок Dactylis glomerata (29,2-38,1 мкм), Poa spp. (26,1-37,3 мкм), Panicum capillare (33,3-39,5 мкм), Lolium perenne (30,4-35,3 мкм), Bromus sterilis (28,3-30,8 мкм). Розмір пилку В. ramоsиs становив від 26,1 до 39,5 мкм, а B. tectorum - від 35 до 38,4 мкм. До категорії найменшого пилку були віднесені пилкові зерна Роа ргаtепsе (22,1-25,9 мкм) ma Piptatherum spp. (20,3-24,1 мкм). Єдиним злаком, розмір пилку якого знаходився у кожній категорії, був Agrostis gigantea. Для різних популяцій цієї рослини ми виявили великі, середні розміри та зерна розміром 25,0-27,7 мкм, які 
лежать між категоріями 2 та 3. Відтак, деякі роди та види Роасеае можна відрізнити за розмірами їхнього пилку, тоді як для інших розміри пилкових зерен значно варіюють. Необхідним $є$ проведення подальших досліджень, які допоможуть встановити морфологію пилку більшої кількості рослин родини Тонконогових, що значно покращить в Україні діагностику та профрілактику сезонної алергії, викликаної пилком злаків.

Ключові слова: алергенний пилок, алергенні біологічні частки, сезонна алергія, пилок злаків, чутливість до пилку, профрілактика полінозу.

\section{ИЗУЧЕНИЕ МОРФОЛОГИИ ПЫЛЬЦЫ ЗЛАКОВ КАК ОСНОВАНИЯ ДЛЯ МОНИТОРИНГА АЛЛЕРГЕННЫХ БИОЛОГИЧЕСКИХ ЧАСТИЦ В АВТОМАТИЧЕСКОМ РЕЖИМЕ \\ Яснюк М.В., Каминская О.А., Родинкова В.В.}

Четкое отличие морфологии аллергенных зерен пыльцы различных родов семейства Тонконоговых (Роасеае) является важной задачей при определении фракторов аллергии у населения. Оно позволяет как значительно повышать эффрективность диагностики сезонной аллергии, вызванной пыльцой злаков, так и создавать более точные прогнозы сезонных рисков для людей, страдающих от аллергии на пыльиу разных видов злаков. Поэтому целью нашего исследования было установление морфологического различия между пыльцевыми зернами растений разных видов семейства Роасеае для дальнейшего определения возможности использования установленных отличий при идентификации пыльцы в аэробиологических исследованиях. Для этого в полевых условиях в течение мая-июня месяцев 2019 года в Виннице собирали гербарные образцы и пыльцу исследуемых растений. Пыльцу стряхивали с пыльников непосредственно на предметное стекло и сразу окрашивали основным ффуксином и закрывали покровным стеклом. Размеры пыльцевых зерен - их ширину и длину - определяли и анализировали с помощью программы PhotoM 1.21, а квартильным методом в программе Ехсеl получили цифрровые данные размеров пыльцы, которые в дальнейшем были разделены на 3 соответствующие категории: большой размер пыльцы, средний и малый. Большие зерна имели параметры ширины и длины 40 мкм и более, средние зерна были от 26 до 39 мкм, а мелкая пыльца составляла 26 мкм и меньше по ширине и длине. В категорию больших вошла пыльца Ногdеит morinum (39,5-53,1 мкм), Elytrigia repens (41-48 мкм), Secale cereale (48,4-62,5 мкм) и Bromus arvensis (42,2-52,7 мкм). Категория средних зерен включала пыльцу Dactylis glomerata (29,2-38,1 мкм), Poa spp. (26, 1-37,3 мкм), Panicum capillare (33,3-39,5 мкм), Lolium perenne (30,4-35,3 мкм), Bromus sterilis (28,3-30,8 мкм). Размер пыльцы B. ramosus составлял от 26,1 до 39,5 мкм, а B. tectorum - om 35 до 38,4 мкм. К категории самой маленькой пыльцы были отнесены зерна пыльцы Poa pratense (22,1-25,9 мкм) и Piptatherum spp. (20,3-24,1 мкм). Единственным злаком, размер пыльцы которого находили в каждой категории, был Agrostis gigantea. Для разных популяций этого растения мы обнаружили большие, средние размеры и зерна размером 25,027,7 мкм, которые лежат между категориями 2 и 3. Следовательно, некоторые роды и виды Роасеае можно отличить по размерам их пыльцы, тогда как у других размеры пыльцевых зерен значительно варьируют. Необходимым является дальнейшее проведение исследований, которые помогут установить морфологию пыльцы большего количества растений семейства Тонконоговых, что значительно улучшит в Украине диагностику и профилактику сезонной аллергии, вызванной пыльцой злаков.

Ключевые слова: аллергенная пыльца, аллергенные биологические частицы, сезонная аллергия, пыльца злаков, чувствительность к пыльце, профолактика поллиноза. 